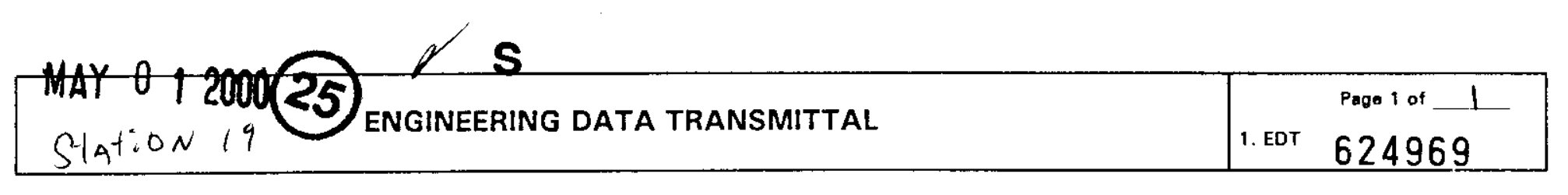

\begin{tabular}{|l|l|}
\hline $\begin{array}{l}\text { 2. To: (Receiving Organization) } \\
\text { Distribution }\end{array}$ & $\begin{array}{l}\text { 3. From: (Originating Organization) } \\
\text { Facility Engineering }\end{array}$ \\
\hline $\begin{array}{l}\text { 5. Proj./Prog./Dept./Div.: } \\
\text { IWTS/SNF Projects/K Basins }\end{array}$ & $\begin{array}{l}\text { 6. Design Authority/Design Agent/Cog. Engr.: } \\
\text { LC Mauws }\end{array}$ \\
\hline $\begin{array}{l}\text { 8. Originator Remark: } \\
\text { The Software Configuration Management Plan provides the instructions } \\
\text { for change control of the K West Basin IWTS. }\end{array}$
\end{tabular}

11. Receiver Remarks:

11A. Design Baseline Document? $\bigotimes$ Yes $\square$ No

\begin{tabular}{l} 
4. Related EDT No.: \\
NA \\
7. Purchase Order No.: \\
NA \\
$\begin{array}{l}\text { 9. Equip./Component No.: } \\
\text { NA }\end{array}$ \\
\hline
\end{tabular}

10. System/Bidg./Facility:

$70.3 / 105 \mathrm{KW} / 100 \mathrm{~K}$

12. Major Assm. Dwg. No.:

NA

13. Permit/Permit Application No.:

USQ K-00-621

NA

14. Required Response Date:

\begin{tabular}{|l|l|}
\hline \multicolumn{2}{|l|}{15.} \\
\hline $\begin{array}{c}\text { (A) } \\
\text { tem } \\
\text { No. }\end{array}$ & (B) Document/Drawing No. \\
\hline 1 & SNF-6247 \\
\hline & \\
\hline & \\
\hline & \\
\hline & \\
\hline & \\
\hline & \\
\hline
\end{tabular}

16.

DATA TRANSMITTED

\begin{tabular}{|l|l|l|}
\hline $\begin{array}{c}\text { (C) Sheet } \\
\text { No. }\end{array}$ & $\begin{array}{c}\text { (D) Rev. } \\
\text { No. }\end{array}$ & (E) Title or Description of Data Transmitted \\
& 0 & Software Configuration \\
\hline & & Management Plan for the KW \\
\hline & & IWTS Control System \\
\hline & & \\
\hline & & \\
\hline
\end{tabular}

\begin{tabular}{|c|c|c|c|}
\hline (F) & $(G)$ & $(H)$ & $(I)$ \\
\hline $\begin{array}{c}\text { Approval } \\
\text { Desig- } \\
\text { nator }\end{array}$ & $\begin{array}{c}\text { Reason } \\
\text { frans- } \\
\text { mittal }\end{array}$ & $\begin{array}{c}\text { Origi- } \\
\text { nator } \\
\text { Dispo- } \\
\text { stion }\end{array}$ & $\begin{array}{c}\text { Receiv- } \\
\text { er } \\
\text { Dispo- } \\
\text { sition }\end{array}$ \\
\hline QSn & 2 & 1 & \\
\hline & & & \\
\hline & & & \\
\hline
\end{tabular}

\begin{tabular}{|c|l|}
\hline Approval Designator $(F)$ & \\
\hline E, S, $Q, D$ OR N/A & 1. Approval \\
$\begin{array}{c}\text { (See WHC-CM-3-5, } \\
\text { Sec. 12.7) }\end{array}$ & 2. Release \\
\hline
\end{tabular}

17.

KEY

Reason for Transmittal (G)
4. Review
5. Post-Review
6. Dist. (Receipt Acknow. Required)

\begin{tabular}{|ll}
$\mid c$ & Disposition (H) \& (I) \\
1. Approved & 4. Reviewed no/comment \\
2. Approved w/comment & 5. Reviewed w/comment \\
3. Disapproved w/comment & 6. Receipt acknowledged
\end{tabular}
SIGNATURE/DISTRIBUTION (See Approval Designator for required signatures)

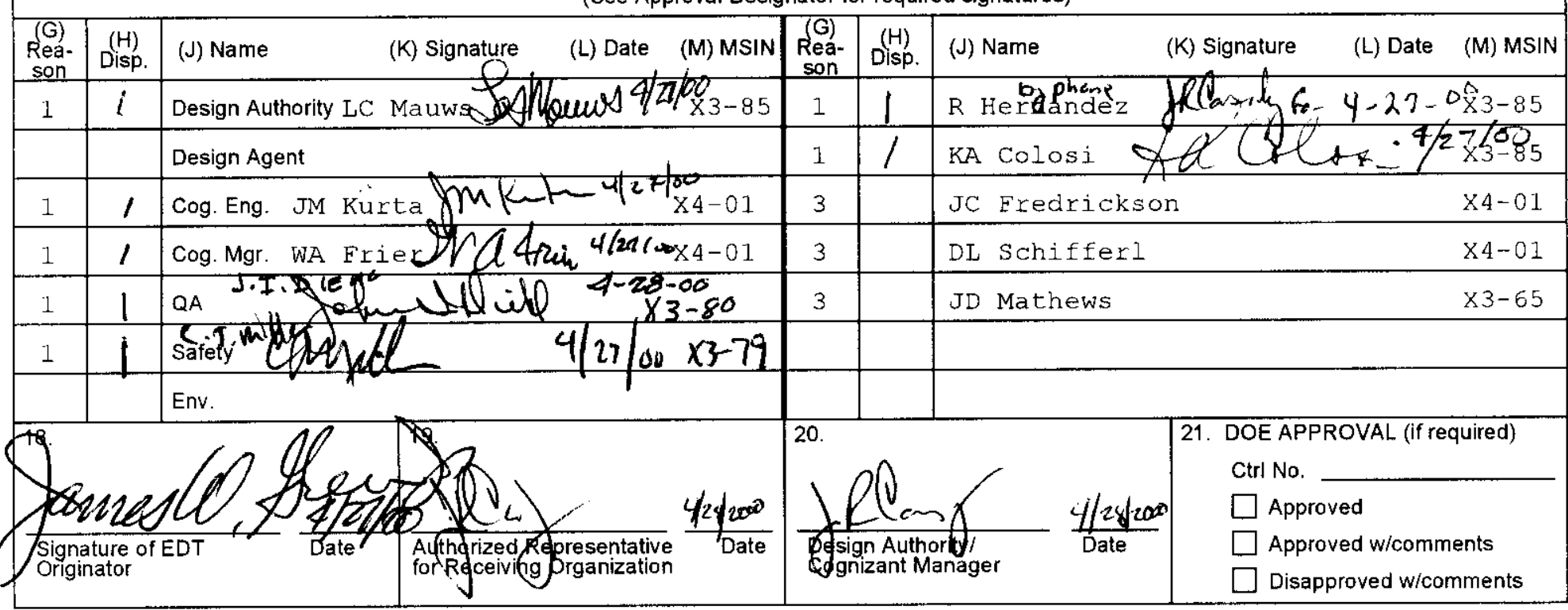


SNF-6247

Revision 0

\section{Software Configuration Management Plan for the K West Basin Integrated Water Treatment System (IWTS) - Project A.9}

Prepared for the U.S. Department of Energy

Assistant Secretary for Environmental Management

Project Hanford Management Contractor for the

U.S. Department of Energy under Contract DE-AC06-96RL13200

\section{Fluor Hanford}

P.O. Box 1000

Richland, Washington 
SNF-6247

Revision 0

EDT 624969

\title{
Software Configuration Management Plan for the K West Basin Integrated Water Treatment System (IWTS) - Project A.9
}

\author{
J. W. Green
}

Fluor Hanford

Date Published

April 2000

Prepared for the U.S. Department of Energy

Assistant Secretary for Environmental Management

Project Hanford Management Contractor for the

U.S. Department of Energy under Contract DE-AC06-96RL13200

Fluor Hanford

P.O. Box 1000

Richland, Washington

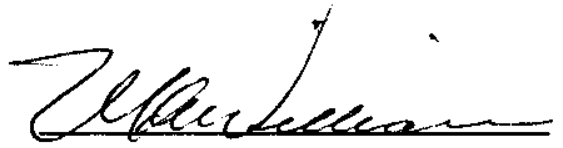

Release Approva

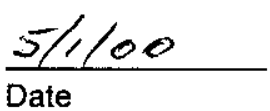

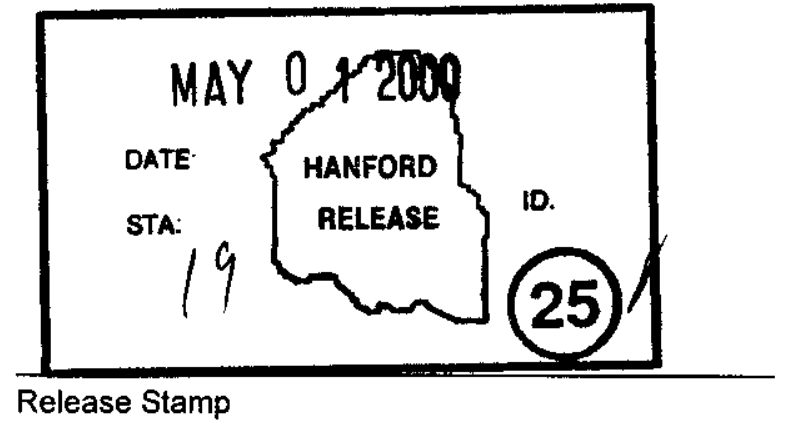




$$
\begin{aligned}
& \text { SNF }-6247 \\
& \text { RW O COKB 4/27/00 }
\end{aligned}
$$

\section{TRADEMARK DISCLAIMER}

Reference herein to any specific commercial product, process, or service by trade name, trademark, manufacturer, or otherwise, does not necessarily constitute or imply its endorsement, recommendation, or favoring by the United States Government or any agency thereof or its contractors or subcontractors.

This report has been reproduced from the best available copy. Available in paper copy and microfiche.

Available electronically at http://www.doe.gov/bridge. Available for a processing fee to the U.S. Department of Energy and its contractors, in paper, from:

U.S. Department of Energy

Office of Scientific and Technical Information

P.O. Box 62

Oak Ridge, TN 37831-0062

Phone: $865-576-8401$

Fax: $865-576-5728$

Email: reports@adonis.Osti.gov(423) 576-8401

Available for sail to the public, in paper, from:

U.S. Department of Commerce

National Technical Information Service

5285 Port Royal Road

Springfield, VA 22161

Phone: 800-553-6847

Fax: 703-605-6900

Email: orders@ntis.fedworld.gov

Online ordering:

http://www.ntis.gov/ordering.htm

Printed in the United States of America

Total Pages: 21 (JKB 4/27/00) 


\section{SOFTWARE CONFIGURATION MANAGEMENT PLAN \\ FOR THE $105 \mathrm{~K}$ WEST INTEGRATED WATER TREATMENT SYSTEM}

\section{TABLE OF CONTENTS}

1.0 INTRODUCTION

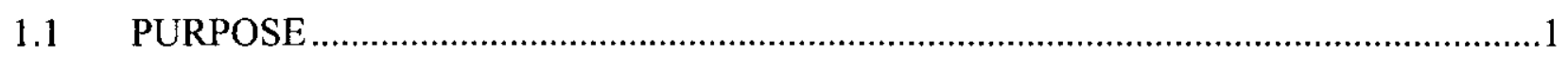

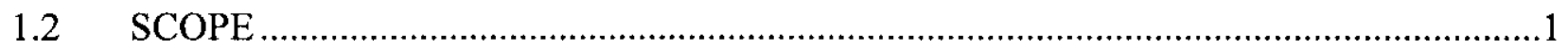

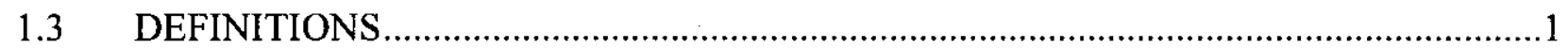

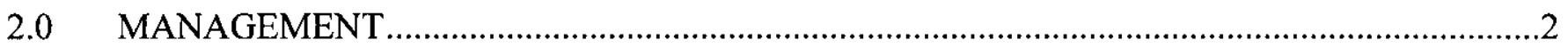

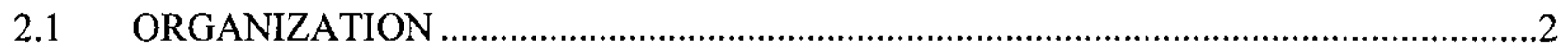

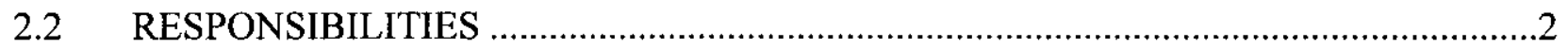

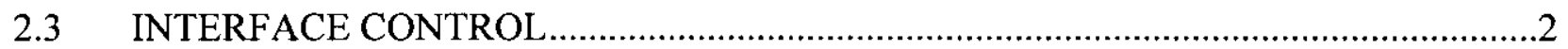

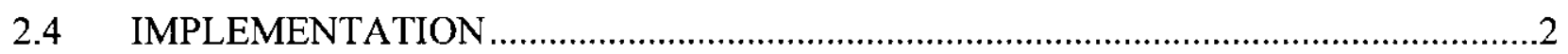

3.0 SOFTWARE CONFIGURATION MANAGEMENT ACTIVITIES ………..................................

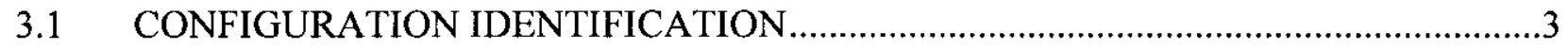

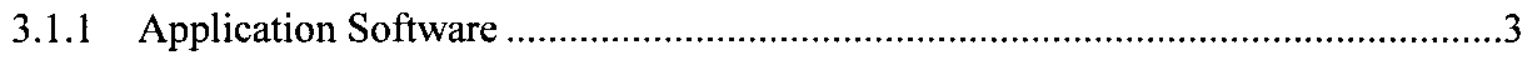

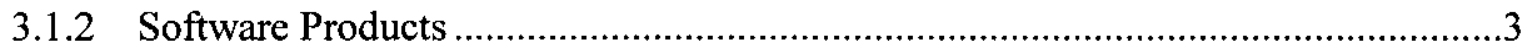

3.1.3 Computer Hardware .......................................................................................4

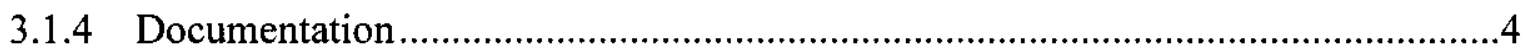

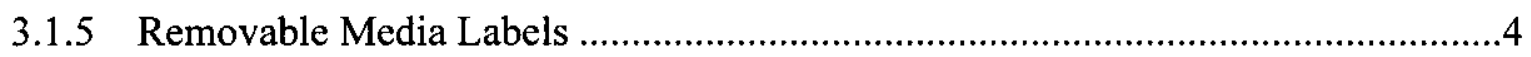

3.1.6 Directory Nomenclature...............................................................................

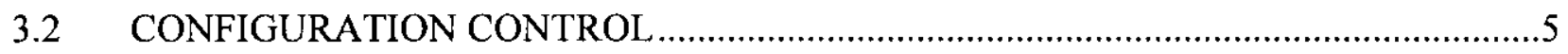

3.2.1 Routine Change ............................................................................................

3.2.2 Software Copies ..................................................................................................

3.3 CONFIGURATION STATUS ACCOUNTING ……...................................................

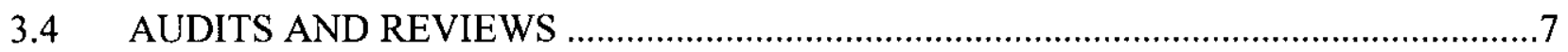

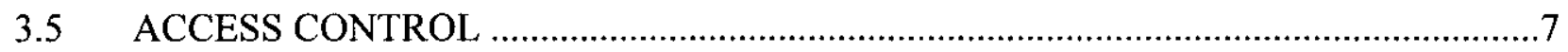

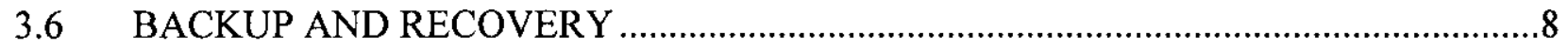

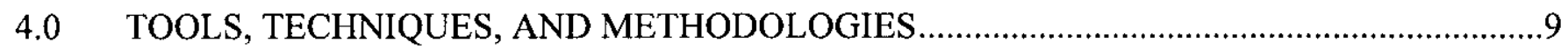

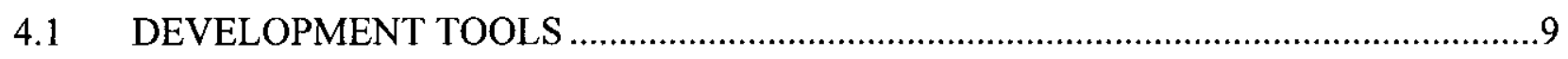

4.1.1 TISOFT TM and Wonderware ${ }^{\mathrm{TM}}$ InTouch 7.0 software …......................................

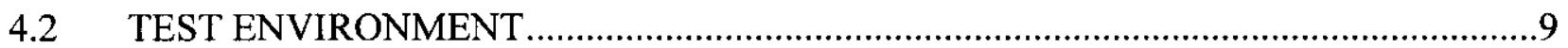




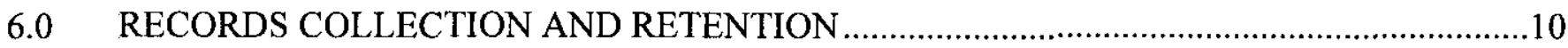

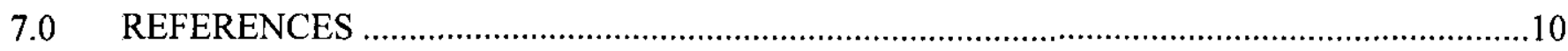

\section{LIST OF APPENDICES}

APPENDIX A Software Change Request or Problem Report Form.

\section{LIST OF TRADEMARKS}

SIMATIC ${ }^{\text {TM }}$ is a registered trademark of Siemens Aktiengesellschaft, Germany.

TISOFT $^{\mathrm{TM}}$ is a registered trademark of TISOFT Inc., Fairfax, Virginia.

Toshiba $^{\mathrm{TM}}$ is a registered trademark of Kabushiki Kaisha Toshiba DBA Toshiba Corporation, Japan.

Windows NT ${ }^{\mathrm{TM}}$ is a registered trademark of Microsoft Corporation, Redmond, Washington.

Wonderware ${ }^{\mathrm{TM}}$ is a registered trademark of Wonderware Corporation, Irvine, California.

\section{Charge Code: 105499 \\ B\&R Code: EW04J1110}

Key Words: K Basin Upgrade, Project A.9, Integrated Water Treatment System (IWTS), Software, Configuration Control

Abstract: This document provides a configuration control plan for the software associated with the operation and control of the Integrated Water Treatment System (IWTS). It establishes requirements for ensuring configuration item identification, configuration control, configuration status accounting, defect reporting and resolution of computer software. It is written to comply with HNF-SD-SNF-CM-001, Spent Nuclear Fuel Configuration Management Plan (Forehand 1998) and HNF-PRO-309 Computer Software Quality Assurance Requirements, and applicable sections of administrative procedure CM-6-037-00, SNF Project Process Automation Software and Equipment. 


\section{SOFTWARE CONFIGURATION MANAGEMENT PLAN FOR THE 105 K WEST INTEGRATED WATER TREATMENT SYSTEM}

\subsection{INTRODUCTION}

\subsection{PURPOSE}

This Software Configuration Management Plan (SCMP) provides the instructions for change control of the K West (KW) Basin Integrated Water Treatment System (IWTS) Control System (CS) Software designed and constructed by Project A.9, KW Basin Upgrade. Refer to SNF-4449, System Description for the KW Basin Integrated Water Treatment System (70.3), (DeRusseau and Precechtel 2000), and administrative procedure CM-6-037-00, SNF Project Process Automation Software and Equipment.

\subsection{SCOPE}

This plan applies to the Siemens SIMATIC ${ }^{\text {TM }} 545$ PLC Programmable Logic Controller (PLC) ladder logic software and the Human Machine Interface (HMI) Wonderware ${ }^{\mathrm{TM}}$ InTouch Systems software operating on the control system located in the $105 \mathrm{KW}$ Building. The CS is located in Room 20A, Control Panel D (CP-D).

Accompanying the control system is a Toshiba ${ }^{\mathrm{TM}}$ T4700 laptop computer. The laptop computer is not required for normal automatic operation, but is used for software development testing, debugging, downloading the software program/code into the PLC, and for administration. The laptop is portable and maintained by the owner/operator of the system. The HMI provides a Graphics Interface to monitor system function and a method for manual control of the system during startup/checkout.

\subsection{DEFINITIONS}

Production: Pertaining to the status of a given system following acceptance by the customer.

Software Change Request and Problem Report (SCR/PR): A document used to identify proposed changes to or suspected problems with the software. An SCR/PR may identify a new function, modify an existing function, or report suspected problems of the software.

Software Configuration Management (SCM): A set of management disciplines within the context of the software engineering process that applies technical and administrative direction and surveillance. It identifies and documents the functional and physical characteristics of a product, controls changes to those characteristics, and it records and reports change processing and implementation. 


\subsection{MANAGEMENT}

\subsection{ORGANIZATION}

Design Authority shall be designated as system owner, operator and maintenance authority.

Software Engineer shall be designated developer, maintainer and custodian until acceptance and process testing of the system has been completed. Once this occurs, the system will be completed and the software transferred to the system owner.

\section{$2.2 \quad$ RESPONSIBILITIES}

Individuals assigned the following roles will be designated by the owner/operator of the system. Current designations will be listed in the change status log maintained by the software custodian.

Design Authority - Review and Approval of all software changes. Authorizes start of implementation. Ensures configuration is compliant with safety basis.

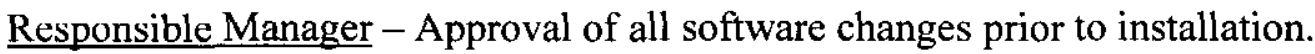

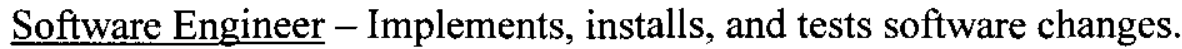

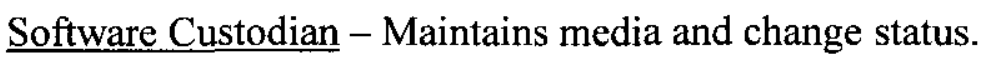

\subsection{INTERFACE CONTROL}

The IWTS Control System does not interface with any other system.

\subsection{IMPLEMENTATION}

This SCMP becomes effective whenever a problem is identified or change request is issued and will be used to maintain configuration control during these periods in lieu of SNF-4671, Integrated Water Treatment System - K West Basin Ladder Logic - Project A.9, (Najjar 2000). Overall responsibility for the SCM activity rests with Design Authority (DA) described in Section 2.2. Version change control of source code and executables becomes effective when released for testing for major revisions, and released for production on minor revisions. 


\subsection{SOFTWARE CONFIGURATION MANAGEMENT ACTIVITIES}

Configuration Management will be applied to the IWTS Control System as described in this section.

\subsection{CONFIGURATION IDENTIFICATION}

\subsubsection{Application Software}

Design basis documentation, which sets the foundation for the configuration of the IWTS Control System, is found in the system description. Refer to SNF-4449 for the System Description, and CM-6-037-00.

The PLC software code is created by TISOFT ${ }^{\mathrm{TM}}$ Version 6.2.2, developed on a personal computer (PC), and is in the form of ladder logic with related configuration database files. Once developed on the PC, the code is downloaded to the Siemens ${ }^{\mathrm{TM}}$ Simatic 545 PLC.

The Human Machine Interface (HMI) software is Wonderware ${ }^{\mathrm{TM}}$ InTouch 7.0 that runs on a Pentium class personal computer with Windows ${ }^{\mathrm{TM}} \mathrm{NT}$ as the operating system. InTouch 7.0 software consists of two major components, WindowMaker ${ }^{\mathrm{TM}}$ (the development environment where touch sensitive display windows are created. These displays are connected to $\mathrm{I} / \mathrm{O}$ and Microsoft ${ }^{\mathrm{TM}}$ Windows applications.), and WindowViewer ${ }^{\mathrm{TM}}$ (the operator graphical display interface), and includes six utility/diagnostic programs. The file types used by the HMI software are described in the Wonderware InTouch 7.0 Users Guide (Vendor Information). The InTouch 7.0 software may be loaded onto the laptop computer or the production PC for development.

Each production software release shall be a grouping of the code and executable software products, and any modifications to vendor software (e.g., configurations, etc.). The release is assigned a unique release number by the developer. Refer to the sample form in the "Release Cover Sheet and Revision Record," Appendix B. The release form shall also note operating system and development tool revision numbers in Section 7 of that form.

\subsubsection{Software Products}

Each software product (e.g., the application software development packages, the operating system software, etc.) is assigned a unique product name and release version number by the appropriate vendor and will be used as identification as much as practical on the software release documentation. 


\subsubsection{Computer Hardware}

Microprocessor controlled hardware, such as installed field components, modules, power supplies, etc., is controlled by normal Hanford administrative procedures (e.g., $\mathrm{H}-2$ or $\mathrm{H}-1$ drawing system via Engineering Data Transmittals (EDT) and Engineering Change Notices (ECN)). Configuration control is required by this $\mathrm{SCMP}$, only for the case of:

1) Identification of the minimum equipment necessary for operation, and

2) Evaluation of impacts caused by field hardware changes that are part of the design basis documentation set - via an SCR/PR.

\subsubsection{Documentation}

SCR/PR forms shall be kept in local Technical Document Control (TDC) project files in log form by the DA. When a release of the IWTS CS software occurs, the DA will establish either 1) a file with the information related to that release, or 2) will produce an SNF document to formally document the release sheet and associated SCR/PRs.

\subsubsection{Removable Media Labels}

Removable media will have the have the following information records on the label:

- Media identifier (i.e., disc number)

- Software identification

- Software revision identification ("R.r", "R" = major and " $r$ " = minor software changes, e.g., 1.0)

- Software or data name or description

- Responsible organization and software custodian's name

- Recording date and time

\subsubsection{Directory Nomenclature}

Original or backup source and executable software placed on media containing multiple versions/revisions shall be segregated using the available directory/ subdirectory structure.

On the production systems, only the most current version will be maintained in a single project directory. For the PLC, the configuration is stored in the PLC memory. For the HMI the configuration will be in the Wonderware ${ }^{\mathrm{TM}}$ InTouch Systems 7.0 directory.

A separate computer with a Wonderware ${ }^{\mathrm{TM}}$ InTouch Systems 7.0 project directory will be maintained for each major release. The user software (Wonderware ${ }^{\mathrm{TM}}$ ) shall be maintained on a zip disk. The vendor software is currently controlled by factory issued compact disk media. For minor releases, changes (edits) will be made directly to the most current major release files. 


\subsection{CONFIGURATION CONTROL}

SCR/PR approvals are recorded and submitted using the SCR/PR form. See Appendix A for an example of the form.

E-mail approvals for processing SCR/PRs may be substituted for handwritten approvals. When e-mail approvals are used a copy of the e-mail approval must be attached to the SCR/PR.

Telephone approvals for processing SCR/PRs may be used, but subsequently, must be documented on the SCR/PR form.

\subsubsection{Routine Change}

\section{Anyone in owner/operator organization:}

- Prepare a SCR/PR to identify a problem with or request a change to the software.

- Ensure that an evaluation is performed of design basis documentation changes (via an SCR/PR and attached ECN with USQ review) for potential changes.

- Forward the SCR/PR to the DA. Include recommendations on how to proceed when appropriate.

\section{DA (or delegate):}

- Ensure the change is compliant with the Safety Basis.

- Determine which SCR/PRs are appropriate and forward to the Software Engineer for analysis and hours estimate.

- Evaluate whether the change is an emergency or routine SCR/PR.

\section{Software Engineer:}

- If routine, assign a SCR/PR Number and enter it in the status log. See example in Appendix A.

- Analyze SCR/PR and estimate hours and impact to complete and implement.

- Determine if SCR/PR requires a major or minor revision.

- Prioritize accepted SCR/PRs. Forward to Software Developer and Maintainer or Software Engineer(s) to perform the work.

- Plan with DA how and to what extent changes to the software will be tested and documented.

- Forward appropriate problem reports to vendor if it is a problem in the vendor's product. 
- Perform the work identified in SCR/PR and conduct tests. Ensure that changes that cannot be tested in a test environment are conducted in a manner that will not have adverse affect on the software production environment.

- Document test results and include with change request, or indicate supporting document number if applicable. Obtain independent review.

- Provide change documentation to Software Custodian.

- Group one or more SCR/PR's into a planned release.

- Evaluate the results of the tests with Independent Reviewers (e.g., the DA, etc.) to determine if the changes (individually and as a whole) are acceptable for a test/production release.

- Schedule implementation with the DA.

- Place source code and executable files for the release on removable media, labeled per Section 3.1.5.

\section{Responsible Manager:}

- Approve or disapprove placing a release in the test/production environment.

\section{Software Custodian:}

- Verifies signatures on documentation.

- Verifies removable media are properly labeled.

- Stores removable media in a media storage cabinet designated by the Software Custodian. This copy shall be treated as the backup release copy.

- Also place source code and executable files on the fileserver backup partition directory identified per license agreement and Section 3.1.6. The partition password shall be controlled by the Custodian and shall be disclosed only to those with a need to know.

- Verify that the SCR/PR closeout is distributed to the initiator and others as appropriate.

- Maintains a configuration status log on the backup server. 


\subsubsection{Software Copies}

Software will be controlled in four locations as follows:

- Production Copy - latest release stored and operating on the production equipment.

- Working Copy - latest release with changes in process stored on the laptop.

- Master Copy - removable media for each major and minor release, labeled and stored by software custodian.

- Backup Copy - duplicate of each master copy stored on the backup server in directories named to correspond to the removable media release numbers.

\subsection{CONFIGURATION STATUS ACCOUNTING}

The configuration status of all controlled items is shown on the Release Cover Sheet (example, Appendix B). In addition, the status of all SCR/PRs and associated releases will be maintained and be available on the backup directory as a log file.

\subsection{AUDITS AND REVIEWS}

The IWTS CS and associated documentation, including software change control, will be available for audit during normal working hours. The Responsible Manager should periodically assess the project file and change control documentation to ensure compliance. Other surveillance and audits are the responsibility of other outside organizations and are outside the scope of this plan.

All changes and tests shall be reviewed (verified) by a technical person. For minor changes and releases, test results may be attached to the SCR/PR.

Should changes require major modifications or enhancements, the DA and Responsible Manager will determine if a formal plan will be prepared. The formal plan will identify appropriate technical and Quality Assurance (QA) reviews consistent with SNF procedures and commensurate with complexity of the change.

\subsection{ACCESS CONTROL}

Access control for programmer and supervisor access of the IWTS CS software is provided by the application. It provides for an authorized user list and associated privilege levels. Authorized users are required to provide a user name and password. Authorized users and passwords for access will be assigned and controlled by the DA or delegate. 


\subsection{BACKUP AND RECOVERY}

Backup of the source code and executable files that constitute each product release is done by the software custodian onto the fileserver backup partition selected and documented by the Software Custodian at the time of release. The Software Custodian is responsible for verifying that the backup is in place and the appropriate files exist.

Recovery shall be accomplished by rewriting the appropriate files from the master media onto the production system. This shall be accomplished by the Software Custodian or Software Engineer as needed. Should the master media be simultaneously corrupt, recovery shall be from the backup fileserver copy. 


\subsection{TOOLS, TECHNIQUES, AND METHODOLOGIES}

\subsection{DEVELOPMENT TOOLS}

\subsubsection{TISOFT ${ }^{\mathrm{TM}}$ and Wonderware ${ }^{\mathrm{TM}}$ InTouch 7.0 software}

The working copies of TISOFT ${ }^{\mathrm{TM}}$ 6.2.2 software are loaded on the laptop computer. Working copies of Wonderware ${ }^{\mathrm{TM}}$ InTouch Systems 7.0 are loaded on a desktop computer. Refer to vendor information on operation and use of these products.

The TISOFT ${ }^{\text {TM }}$ 6.2.2 software does not have a simulation feature. However, the PLC ladder logic can be viewed, edited, and saved on the laptop and downloaded onto the PLC. The logic is loaded via a COM port and communications cable. Once the laptop (with TISOFT ${ }^{\mathrm{T}}$ ) is connected to the PLC, TISOFT $^{\text {TM }}$ permits live viewing, editing, and forcing of logic states. This facilitates testing and debugging. Caution should be used when operating TISOFT ${ }^{\mathrm{TM}}$ in this mode since the PLC is in actual control of field devices.

The Wonderware ${ }^{\mathrm{TM}}$ InTouch 7.0 software permits execution of the HMI application in a simulated I/O mode. This facilities testing and debugging. Once tested and approved for release, the HMI application can be transferred via a SERIAL link to the production machine. Once transferred, the application should be recompiled on the production machine before execution.

\subsection{TEST ENVIRONMENT}

All IWTS CS software modifications and enhancements will be completed in a test environment where possible. These changes will be implemented into the production environment only after the DA has reviewed and approved the test results and the Responsible Manager has approved the implementation. Modifications and enhancements will be grouped logically into production releases.

\subsection{SUPPLIER CONTROL}

The Software Engineer will ensure that new releases and installation of the vendor application and software product are tested prior to its being placed in production. Changes in vendor application and/or software product will be processed as a Software Change Request or Problem Report (SCR/PR) with the same approval requirements as a locally generated change.

The Software Engineer will maintain a software project file or binder of all software-related project documentation, correspondence, and project-produced documents. Vendor provided materials and manuals will be maintained by the Software Custodian. This software project file or binder will maintain the most current version of all documents for the life of the system. 
SNF-6247, Rev. 0

Project A.9

\subsection{RECORDS COLLECTION AND RETENTION}

The IWTS Control System Software Engineer will process software development and maintenance records in accordance with HNF-PRO-2778, IRM Application Software System Life Cycle Standards (Appendix A, Sections 8 and 9). Any items indicating "Forward to Records Management..." will instead be sent to the Responsible Manager. These records include, at a minimum the SCR/PR log and $\mathrm{SCR} / \mathrm{PR}$ form entries, and will be kept by the DA in local project files.

\subsection{REFERENCES}

CM-6-037-00, Rev. 0, SNF Project Process Automation Software and Equipment, Fluor Hanford, Inc., Richland, Washington.

Derusseau, R. R. and D. R. Precechtel, 2000, System Description for the $K$ West Basin Integrated Water Treatment System (70.3), SNF-4449, Revision 0, Fluor Hanford, Inc., Richland, Washington.

Forehand, G. D., 1998, SNF Configuration Management Plan, HNF-SD-SNF-CM-001, Revision 3, Duke Engineering Services Hanford, Richland, Washington.

HNF-PRO-309, Rev. 1, Computer Software Quality Assurance Requirements, Fluor Hanford, Inc., Richland, Washington.

HNF-PRO-2778, Rev. 0, IRM Application Software System Life Cycle Standards, Fluor Hanford, Inc., Richland, Washington.

Najjar, S. A., 2000, Integrated Water Treatment System - K West Basin Ladder Logic-Project A.9, SNF-4671, Revision 2, Fluor Hanford, Inc., Richland, Washington. 
SNF-6247, Rev. 0

Project A.9

APPENDIX A

SOFTWARE CHANGE REQUEST AND PROBLEM REPORT FORM

CONSISTING OF 3 PAGES

INCLUDING COVERSHEET

Page A-1 
SNF-6247, Rev. 0

Project A.9

APPENDIX A

\section{SOFTWARE CHANGE REQUEST OR PROBLEM REPORT}

NOTE: Submitter Fills In Parts 1-8 (NON-GRAY)

1. SCR Type: [ ] Problem [ ] Enhancement

DESIGN AUTHORIT Y USE ONLY

2. Submitted By:

3. Project Name:

4. Software Program Name:

5. Submitter's Priority [ ]

( $1=$ Critical $2=$ Very Important $3=$ Important $4=$ Inconvenient $5=$ =Interesting)

SCR Number.

Date:

TPCN, W/O, Task Order

Current VerRev:

6. Requested

Completion Date:

7. Task/Change/Problem Title (One Sentence Description):

8. Detailed Description/Justification (Attach Additional Sheet If Necessary):

DESIGN AUTHORTYY USE ONLY:

Decision By:

Assigned To:

Solution Comments/Impact:

Software Programs, Modules or Files Affected:

Task Completed By:

Date:

Verified By:

Date:

Actual Release Version:

Date:

Closed By:

Date:

\section{Software Change Request Or Problem Report Resolution In formation}

\section{[ J Accept [ ] Modify I Reject I IDefer}

Target Release Date: 


\section{Instructions for the Software Change Request or Problem Report}

These instructions are for preparing the Change Request or Problem Report. If more space is needed, use blank pages and attach them to the SCR/RP form. This will be the record of the change request or problem report.

Anyone may submit a Change Request or Problem Report:

1. Indicate if this is a problem report or request for enhancement.

2. Record the name of the person submitting the form and the date.

3. Enter IWTS A.9 for project.

4. Enter IWTS A.9 for software program name.

5. Record submitter's evaluated priority as shown.

6. Provide a requested completion date, or leave blank if unknown.

7. Provide a single sentence title or problem or enhancement.

8. Provide a description of the changes requested or the problems being reported. Provide justification if this is a change request. Attach additional sheets if necessary.

Design Authority (DA):

a. On receipt, enter into the IWTS A.9 SCR/PR Log. Enter the next SCR number on the form.

b. Enter the date received.

c. Enter the charge number if known, otherwise, leave blank.

d. Enter current Version/Revision of the product.

e. Review change request or problem with manager. Note that SCR/RP may require attached cost estimate and planning if extensive changes or testing are anticipated. Mark accept, modify, reject or defer as appropriate.

f. DA signs "decision by" block, and assigns to Software Engineer, if accepted.

g. Assigns a Software Engineer in the Assigned To Field and a Target Release Date as appropriate.

h. Software Engineer fills in solution, impacts and comments area, and identifies programs, modules and files to be affected. A list may be attached. Also documents/performs testing as identified by the DA and attaches test results or additional verification documentation.

i. Software Engineer signs "Task Completed by" block and passes to independent reviewers.

j. Independent reviewer(s), at a minimum including the DA, signs "Verified By" blocks.

$\mathrm{k}$. When included in a release, place release version in "Actual Release Version" block.

1. DA signs "Closed By" block when complete or rejected. 
SNF-6247, Rev. 0

Project A.9

\begin{abstract}
APPENDIX B
RELEASE COVER SHEET \& REVISION RECORD FORM AND INSTRUCTIONS
\end{abstract}

CONSISTING OF 3 PAGES INCLUDING COVERSHEET

Page B-1 
SNF-6247, Rev. 0

Project A.9

\section{APPENDIX B}

\section{RELEASE COVER SHEET \& REVISION RECORD}

1. Software ID (Name):

Rev.:

2. Release Type: [] Initial Release [] Change [] App Des [] Sfty Cls

3. Abstract

4. Software Files (or attach directory listing)

5. Software files record storage media and location

\begin{tabular}{|c|c|c|c|}
\hline 6. Documentation & Title & Number & Rev \\
\hline \multicolumn{4}{|l|}{ Requirements } \\
\hline \multicolumn{4}{|l|}{ Design } \\
\hline \multicolumn{4}{|l|}{ Design Verif. } \\
\hline \multicolumn{4}{|l|}{ Validation } \\
\hline \multicolumn{4}{|l|}{ User } \\
\hline \multicolumn{4}{|l|}{ Config. Cntl. } \\
\hline 7. Environment & Description & Rev & IL/Safety Class \\
\hline \multicolumn{4}{|l|}{ Hardware } \\
\hline \multicolumn{4}{|l|}{ Oper. Software(s) } \\
\hline \multicolumn{4}{|l|}{ Language(s) } \\
\hline Comm. Networks & & & \\
\hline
\end{tabular}

8. Released for:

[ ] Integration [ ] Operational Test [] Operation

9. Approvals

Software Engineer:

Date

Design Authority:

Date:

Software Custodian:

Date: 


\section{Instructions for the Release Cover Sheet \& Revision Record}

Fill out as indicated:

1. Provide Software Name and new revision number.

2. Check release type. Indicate Approval Designator and Safety Class (SC, SS, GS).

3. Provide an abstract describing the product being released. Indicate if only a portion of the software is being modified.

4. List all source and executable files that are being released, and where they reside. Attaching a directory listing is acceptable, if it includes the full names of the file, creation date and time (combination is version identification). Date on all files may be set to release data, time may beset to indicate the release version number (e.g. 2.07a).

5. Indicate source and executable file master type (floppy disk, optical, magnetic tape), media serial number and storage location. This media will be held by the software custodian.

6. List the documentation components for the release.

7. List the operational environment for the release.

8. Check the reason/limits for the release.

9. Provide approval signatures as required by SCMP. 


\section{DISTRIBUTION SHEET}

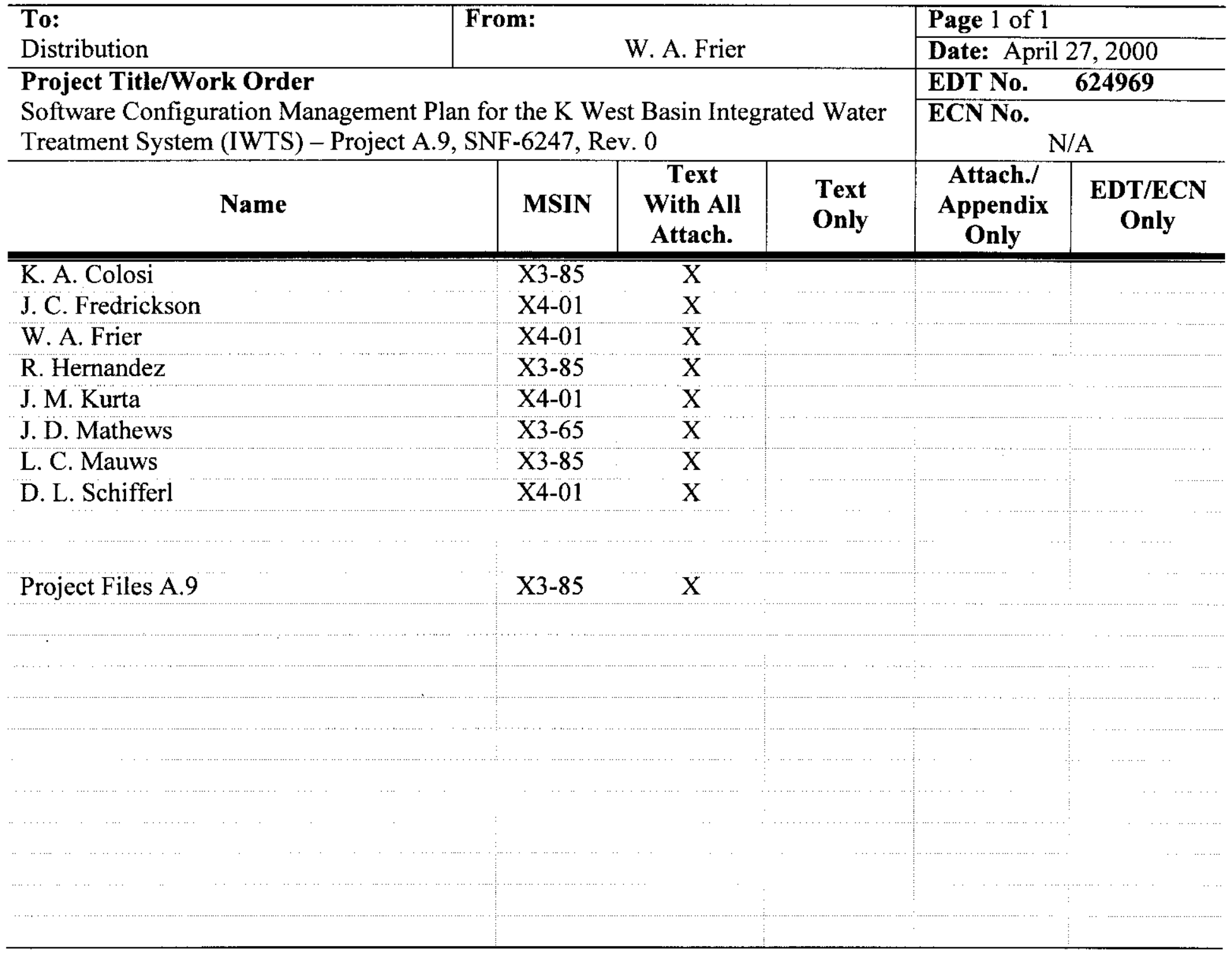

